\title{
The Role of Neuropeptide Y in the Expression and Extinction of Fear-Potentiated Startle
}

\author{
Alisa R. Gutman, Yong Yang, Kerry J. Ressler, and Michael Davis \\ Department of Psychiatry and Behavioral Sciences, Emory University School of Medicine and Center for Behavioral Neuroscience, Atlanta, Georgia 30329
}

Neuropeptides are a promising target for novel treatments for anxiety and other psychiatric disorders and neuropeptide Y (NPY) has emerged as a key component of anxiolytic circuits in the brain. For this reason, we have evaluated the role of NPY in the expression and extinction of conditioned fear. We found that intracerebroventricular administration of NPY inhibits both baseline acoustic startle and the expression of fear-potentiated startle. Infusion of NPY $(10 \mathrm{pmol} / \mathrm{side})$ into the basolateral, but not the medial, nucleus of the amygdala reproduced the intracerebroventricular effect. Central administration of NPY (10 $\mu \mathrm{g})$ also enhanced within-session extinction of fearpotentiated startle. This finding, coupled with the growing body of literature correlating NPY with resilience in humans, led us to the hypothesis that NPY may enhance the extinction of conditioned fear. When NPY (10 $\mu \mathrm{g})$ is administered intracerebroventricularly before extinction training, extinction retention for both the contextual and cued components of conditioned fear is enhanced when tested $48 \mathrm{~h}$ later off drug. Additionally, we found that intra-basolateral amygdala administration of the NPY Y 1 receptor antagonist BIBO 3304 (200 $\mathrm{pmol} / \mathrm{side}$ ) before extinction training led to a profound deficit in extinction retention. This is the first evidence that NPY facilitates and an NPY antagonist blocks the extinction of conditioned fear. We believe that the role of NPY in the extinction of conditioned fear may, at least in part, explain the mechanism underlying the association between NPY and psychobiological resilience in humans.

Key words: neuropeptide; extinction; fear; startle; rat; basolateral amygdala; amygdala; behavior

\section{Introduction}

While traditional psychiatry research has focused on understanding "what goes wrong" in individuals with psychiatric disease, other studies have tried to analyze "what goes right" in individuals who do not develop psychopathology even when exposed to trauma and other risk factors for illness. More precisely, the importance of identifying resilience factors in addition to vulnerability factors is being recognized. Neuropeptide Y (NPY) has emerged as a potentially important component of resiliency systems in the brain.

While a few studies support a role for NPY in learning (Flood et al., 1989; Nakajima et al., 1994; Redrobe et al., 2004), most involve its role in stress and anxiety. Changes in NPY fiber staining and mRNA expression are observed in the hippocampus and amygdala following both acute and chronic restraint stress (Thorsell et al., 1998, 1999; Conrad and McEwen, 2000; Teppen and Urban, 2003) and overexpression of NPY attenuates behavioral responses to stress (Thorsell et al., 2000; Primeaux et al., 2005).

Intracerebroventricular or intra-amygdala infusion of NPY

Received May 21, 2008; revised Sept. 5, 2008; accepted 0ct. 4, 2008.

This work was supported by National Institutes of Health (NIH) Grant MH047840, the Center for Behavioral Neuroscience (National Science Foundation agreement IBN-987675), and by an NIH/National Center for Research Resources base Grant (P51RR000165) to Yerkes National Primate Research Center. We thank members of the Davis laboratory for their support and insightful comments.

Correspondence should be addressed to Dr. Michael Davis, Robert W. Woodruff Professor, Department of Psychiatry and Behavioral Sciences, Center for Behavioral Neuroscience, Yerkes Research Center, Emory University, 954 Gatewood Drive, Atlanta, GA 30329. E-mail: mdavis4@emory.edu.

DOI:10.1523/JNEUROSCI.2305-08.2008

Copyright $\odot 2008$ Society for Neuroscience ～0270-6474/08/2812682-09\$15.00/0 leads to an anxiolytic behavioral profile in several animal models (Flood et al., 1989; Heilig et al., 1992; Broqua et al., 1995; Heilig, 1995; Britton et al., 1997; Sajdyk et al., 1999; Kokare et al., 2005). NPY colocalizes with GABA in local circuit neurons of the basolateral amygdala (BLA) (McDonald and Pearson, 1989) and likely exerts inhibitory control on BLA projection neurons. The anxiolytic effects of NPY generally involve the $\mathrm{Y}_{1}$ receptor (Heilig, 1995; Wieland et al., 1995; Kask et al., 1999; Sajdyk et al., 1999; Primeaux et al., 2005), although $\mathrm{Y}_{2}$ and $\mathrm{Y}_{5}$ receptors have also been implicated (Sajdyk et al., 2002a,b). Most germane to the question of resilience, Sajdyk et al. (2008) found that injections of NPY into the BLA blocked the anxiogenic effects of a chemical or physical stressor, an effect that persisted for 8 weeks after a series of NPY infusions into the BLA. Furthermore, NPY fiber staining in the hippocampus and amygdala is increased when rats are exposed to a fearful context (Teppen and Urban, 2003), and in the BLA when exposed to a cue (A. R. Gutman, K. J. Ressler, and M. Davis, unpublished observations). Together these results led us to ask the mechanistic question, "How could increased levels of NPY be protective?"

We hypothesized that NPY-induced resilience may result because it enhances extinction of conditioned fear. To test this, we first needed to characterize the effects of NPY on cued fear conditioning and then determine whether NPY might modulate extinction learning.

\section{Materials and Methods}

Animals

The procedures used were approved by the Institutional Animal Care and Use Committee of Emory University and in compliance with Na- 


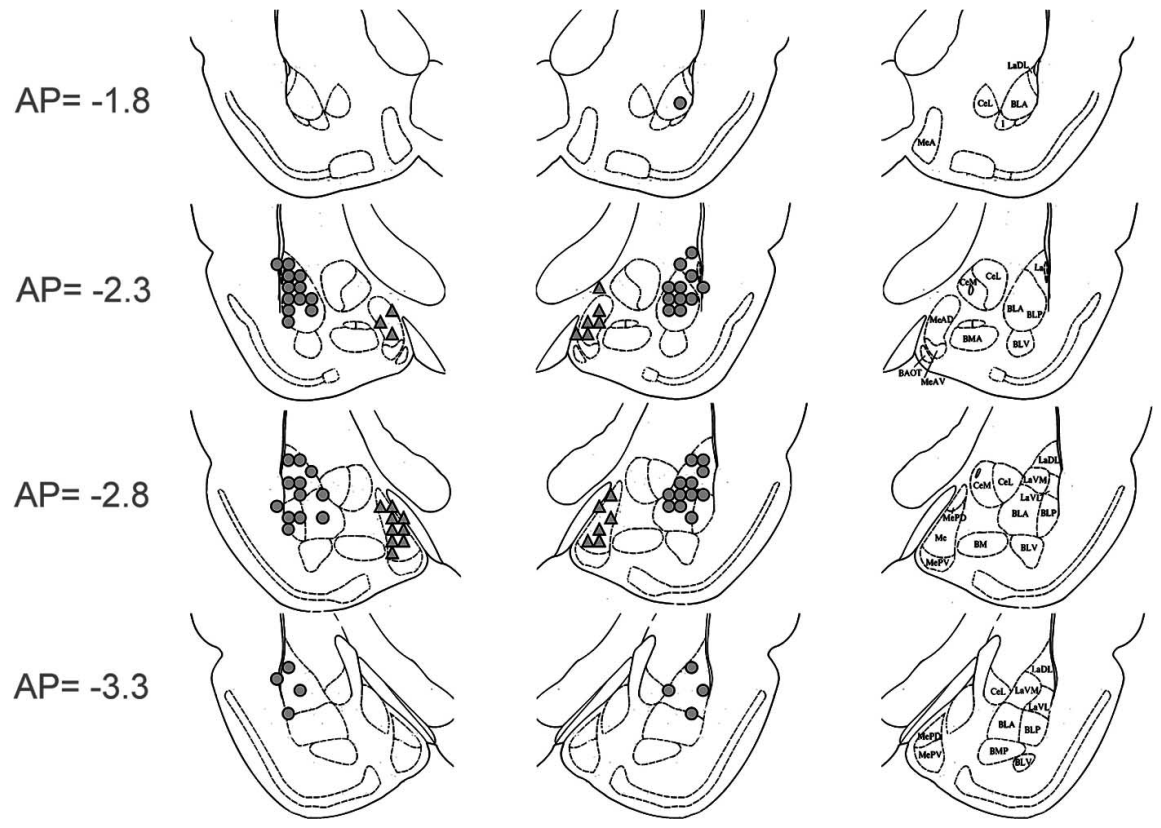

Figure 1. Cannula placements for BLA (circles) and MeA (triangles) in experiments 3, 4, and 8.

and delivered through the same speakers used to provide background noise. An accelerometer (model U321AO2; PCB Piezotronics) affixed to the bottom of each cage produced a voltage output proportional to the velocity of cage movement. This output was amplified (model 483B21; PCB Piezotronics) and digitized on a scale of $0-2500 \mathrm{U}$ by an InstruNET device (model 100B; GW Instruments) interfaced to a Macintosh G3 computer. Startle amplitude was defined as the maximal peak-to-peak voltage that occurred during the first $200 \mathrm{~ms}$ after onset of the startle-eliciting stimulus. The CS was a $3.7 \mathrm{~s} \mathrm{light}$ ( 82 lux) produced by an $8 \mathrm{~W}$ fluorescent bulb (100 $\mu$ s rise time) located $10 \mathrm{~cm}$ behind each cage. Luminosity was measured using a VWR light meter. The US was a $0.5 \mathrm{~s}$ shock, delivered to the floorbars and produced by a shock generator (SGS-004; Lehigh Valley). Shock intensities (measured as in Cassella et al., 1986) were $0.4 \mathrm{~mA}$. The presentation and sequencing of all stimuli were under the control of the Macintosh G3 computer using customdesigned software (The Experimenter; Glassbeads).

\section{Drugs}

NPY (Bachem Biosciences) and $(R)-N-[[4-$

tional Institutes of Health (NIH) guidelines for the care and use of laboratory animals. Adult male Sprague Dawley rats (Charles River) weighing between 350 and $500 \mathrm{~g}$ were used. Animals were housed in groups of four in a temperature-controlled $\left(24^{\circ} \mathrm{C}\right)$ animal colony, with ad libitum access to food and water. They were maintained on a $12 \mathrm{~h}$ light/dark cycle with lights on at 8:00 A.M., with all behavioral procedures performed during the rats' light cycle.

\section{Surgery}

For studies using intracerebroventricular drug administration, 22 gauge stainless-steel guide cannulae (Plastics One) were implanted under ketamine/xylazine anesthesia, and secured using dental cement and 1/8" cap screws (coordinates: AP: 0, ML: -1.6 , DV: -5.0 ; nosebar: +5.0). Animals were allowed $7-10 \mathrm{~d}$ recovery before habituation to the testing context and subsequent behavioral testing. Similar procedures were used to implant bilateral cannulae aimed at the basolateral complex of the amygdala (22 gauge guide cannulae, AP: -3.1 , ML: \pm 5.4 , DV: -8.4 from bregma; nosebar: -3.6$)$ and medial nucleus of the amygdala (MeA) (22 gauge guide cannulae, AP: -2.76 , ML: $\pm 3.5, \mathrm{DV}:-8.5$ from dura) (Fig. 1 ). We used the medial amygdala as a control for regional specificity, because it also expresses NPY receptors and peptide (Chronwall et al., 1985; Parker and Herzog, 1999; Kopp et al., 2002). Following behavioral testing, cannulated animals were killed and cannula placement was assessed on cryostat-sectioned tissue. Animals with both cannulae correctly placed either intracerebroventricularly or within the amygdala were included for analysis.

\section{Startle apparatus}

Animals were trained and tested in $8 \times 15 \times 15 \mathrm{~cm}$ Plexiglas and wiremesh cages, with floors consisting of four $6.0-\mathrm{mm}$-diameter stainlesssteel bars spaced $18 \mathrm{~mm}$ apart. Each cage was suspended between compression springs within a steel frame and located within a customdesigned $90 \times 70 \times 70 \mathrm{~cm}$ ventilated sound-attenuating chamber. Background noise ( $60 \mathrm{~dB}$ wide-band) was provided by a General Radio Type 1390-B noise generator and delivered through high-frequency speakers (Radio Shack Supertweeter; Tandy) located $5 \mathrm{~cm}$ from the front of each cage. Sound level measurements (sound pressure level) were made with a Bruel and Kjaer model 2235 sound-level meter (A scale; random input) with the microphone (Type 4176) located $7 \mathrm{~cm}$ from the center of the speaker (approximating the distance of the rat's ear from the speaker). Startle responses were evoked by $50 \mathrm{~ms}$, $95 \mathrm{~dB}$ white-noise bursts generated by a Macintosh G3 computer sound file $(0-22 \mathrm{kHz})$, amplified by a Radio Shack amplifier (100 W; model MPA-200; Tandy), aminocarbonylaminomethyl)-phenyl] methyl]- $N^{2}$-(diphenylacetyl)argininamide trifluoroacetate (BIBO 3304, given as a generous gift from Dr. Marcus Schindler, Boehringer-Ingelheim, Biberach, Germany) were suspended in artificial CSF with 1\% bovine serum albumin. BIBO 3304 is a highly selective antagonist for the $\mathrm{Y}_{1}$ receptor with subnanomolar affinity for both the human and rat receptors ( $\mathrm{IC}_{50}$ values $0.38 \pm 0.06 \mathrm{nM}$ and $0.72 \pm 0.42 \mathrm{nM}$, respectively) and shows minimal activity in $>75$ different receptor binding and enzyme systems, including 1000- to 10,000-fold lower affinity for the NPY $\mathrm{Y}_{2}, \mathrm{Y}_{4}$, and $\mathrm{Y}_{5}$ receptors $\left(\mathrm{IC}_{50}\right.$ values $>1000 \mathrm{~nm}$ ) (Wieland et al., 1998). Some studies have used the inactive $(S-)$ enantiomer, BIBO 3457, as a control for nonspecific effects of drug. However, since our study includes both agonist and antagonist experiments that yield complementary results, we felt that a vehicle control was sufficient. All infusions were given through microinjection cannulae (28 gauge) connected with PE-20 tubing to a $10 \mu$ l Hamilton syringe. Intracerebroventricular infusions were administered at a flow rate of $10 \mu \mathrm{l} / \mathrm{min}$ with a total injection volume of $5 \mu \mathrm{l}$. Intra-amygdala infusions were administered at a flow rate of $0.25 \mu \mathrm{l} / \mathrm{min}$ with a total injection volume of $0.5 \mu \mathrm{l} / \mathrm{side}$. Microinjection cannulae were left in place for 2-5 $\mathrm{min}$ (intra-BLA and i.c.v., respectively) to allow for diffusion away from cannulae to prevent backflow.

\section{Baseline startle testing}

Animals were placed in the startle chambers for $20 \mathrm{~min}$ on each of $2 \mathrm{~d}$ before training to habituate them to the test procedures and chambers and to minimize the effects of contextual conditioning. Baseline startle testing consisted of a $5 \mathrm{~min}$ habituation period followed by 30 startle stimuli ( $50 \mathrm{~ms}, 95 \mathrm{~dB}$ white-noise burst).

\section{Fear conditioning}

On 2 consecutive days following baseline testing, rats were returned to the same chambers and presented with 10 pairings of a light $(3.7 \mathrm{~s})$ coterminating with a $0.4 \mathrm{~mA}, 0.5 \mathrm{~s}$ shock ( 4 min variable intertrial interval).

\section{Matching for fear-potentiated startle levels}

Twenty-four hours following the last fear-conditioning session, animals were returned to the same chambers and presented with startle stimuli ( $50 \mathrm{~ms}, 95 \mathrm{~dB}$ white-noise bursts) in the presence or absence of the light conditioned stimulus [ 5 light-noise compounds (LN) and 5 noise-alone trials (NA)]. Increased startle in the presence of the light-CS was taken as a measure of conditioned fear, and the magnitude of the fear response 
was calculated as the percentage by which startle increased when elicited in the presence of light-CS versus when it was omitted (percentage fearpotentiated startle: $[(\mathrm{LN}-\mathrm{NA}) / \mathrm{NA}] \times 100)$. Using these measurements, animals were divided into groups displaying equivalent levels of fear-potentiated startle before testing with NPY.

\section{Behavioral procedures}

Experiment 1: the effect of central NPY on baseline startle. Animals $(n=16)$ were tested for effects of NPY on baseline startle using a within-subjects repeated measures design in which each animal received an intracerebroventricular infusion of $0,1,3$, or $10 \mu \mathrm{g}$ of NPY on each of four days in a counterbalanced manner. Drug was infused 60 min before baseline startle testing and statistics among the four drug groups were analyzed using a one-way repeated-measures ANOVA.

Experiment 2: the effect of central NPY on the expression of fearpotentiated startle. To evaluate levels of expression of fear-potentiated startle, animals were returned to the chamber and presented with a 46 min test similar to that described for matching, but consisting of a 5 min acclimation period followed by $30 \mathrm{LN}$ and 30 NA trials. Animals $(n=11)$ were infused intracerebroventricularly with $10 \mu \mathrm{g}$ of NPY or vehicle 60 min before testing. Interval between infusion and testing and drug dose were based on previous studies (Heilig et al., 1989; Broqua et al., 1995). A within-subjects crossover design was used in which half the rats were infused with NPY on day 1 and vehicle on day 2 and the other half administered drugs in the opposite pattern with $48 \mathrm{~h}$ between day 1 and day 2 . The data were analyzed using a paired $t$ test.

Experiment 3: the effect of amygdala administration of NPY on the expression of fear-potentiated startle. To evaluate levels of expression of fear-potentiated startle, animals were returned to the chamber and presented with a 46 min test consisting of a 5 min acclimation period followed by $30 \mathrm{LN}$ and $30 \mathrm{NA}$ trials. We used a within-subjects crossover design, and animals were given $1 \mathrm{~d}$ of re-training before their second expression test to reduce the probability that extinction during the day 1 test session would influence the day 2 test data. The magnitude of fearpotentiated startle was calculated as for matching above. Animals were infused bilaterally immediately before the expression test with vehicle or $10 \mathrm{pmol}$ of NPY/side into either the basolateral $(n=13)$ or medial amygdala $(n=10)$. This dose has been used previously and has consistently shown behavioral effects in anxiety paradigms (Sajdyk et al., 1999). Values for percentage fear-potentiated startle were grouped into blocks of 5 trials each and statistics were performed using a two-way repeatedmeasures ANOVA with block (1-5) and treatment (vehicle, NPY) as factors.

Experiment 4: the effect of amygdala administration of an NPY Y1 receptor antagonist on the expression of fear-potentiated startle. For experiment 4 , animals were infused bilaterally with vehicle $(n=20)$ or $200 \mathrm{pmol} /$ side BIBO 3304 into either the BLA $(n=15)$ or medial $(n=7)$ amygdala immediately before an expression test consisting of a 5 min acclimation period followed by $30 \mathrm{LN}$ and $30 \mathrm{NA}$ trials. Comparisons between groups were performed using two-way repeated-measures ANOVA. The intraamygdala dose of BIBO 3304 was chosen from previous studies in an anxiety paradigm (Sajdyk et al., 1999; Wierońska et al., 2004).

Extinction studies. Because we had found previously that NPY significantly decreased baseline startle, which can cause interpretive problems when evaluating extinction data, all extinction tests were performed $48 \mathrm{~h}$ after NPY infusion. Results from experiments 1 and 2 indicated that this was long enough for the drug to no longer affect baseline startle or expression of startle and we could thereby measure extinction retention without concerns of lingering drug effects. An exception was when determining the effects of NPY on within-session extinction, wherein the drug had to be given right before testing to measure its effects on extinction.

Preextinction test. Twenty-four hours following the last fearconditioning session, animals were returned to the same chambers and given a short test to evaluate fear-potentiated startle (5 CS alone and 5 light-CS test trials). Using these measurements, animals were divided into groups displaying equivalent levels of fear-potentiated startle before extinction training.

Experiment 5: effect of intracerebroventricular NPY on within-session extinction. Animals were returned to the chamber and presented with a 46 min test consisting of a 5 min acclimation period followed by $30 \mathrm{LN}$ and 30 NA trials to evaluate levels of within-session extinction. Animals $(n=11)$ were infused intracerebroventricularly with $10 \mu \mathrm{g}$ of NPY or vehicle $60 \mathrm{~min}$ before testing. Interval between infusion and testing and drug dose were based on previous studies (Heilig et al., 1989; Broqua et al., 1995). A within-subjects crossover design was used and the drug was allowed to wash out for $48 \mathrm{~h}$ before testing with the other condition. Data were analyzed using a two-way repeated-measures ANOVA with block ( 5 trials/block, blocks 1-6) and treatment (vehicle, NPY) as factors.

Experiment 6: effect of intracerebroventricular NPY on extinction retention. Five days following the last fear conditioning session, animals were administered $10 \mu \mathrm{g}$ of NPY $(n=10)$ or vehicle $(n=10)$ intracerebroventricularly $30 \mathrm{~min}$ before the presentation of 30 light-CSs (light-alone, LA) in the absence of footshock (3.7 s light, $30 \mathrm{~s}$ intertrial interval). Relative level of extinction retention was evaluated $48 \mathrm{~h}$ later with a retention test (15 LN and $15 \mathrm{NA}$ ). Fear-potentiated startle was calculated as it was for the preextinction test and data were analyzed using an unpaired $t$ test to compare percentage fear-potentiated startle and twoway repeated-measures ANOVA to compare NA values in the baseline startle, preextinction, and postextinction tests.

Experiment 7: effect of intracerebroventricular NPY on extinction retention with context shift. Because experiment 2 showed that NPY facilitated extinction of context conditioning, which made it difficult to evaluate its effects on cued conditioning, animals in this study were fear conditioned in one context (A), as previously described, but then given extinction training in another context (B). Context B consisted of the following elements: (1) sandpaper inserts placed over the floorbars, (2) 4 chains hanging down from the top of the cage, (3) Velcro inserts placed over the side walls, and (4) cotton soaked in $100 \%$ ethanol below the cage inside of the chamber. Five days following the last fear conditioning session, animals were placed into context B and administered $10 \mu \mathrm{g}$ of NPY $(n=7)$ or vehicle $(n=7)$ intracerebroventricularly $30 \mathrm{~min}$ before the presentation of 30 LA. Relative level of extinction retention was evaluated $48 \mathrm{~h}$ later in context B with a retention test ( $15 \mathrm{LN}$ and $15 \mathrm{NA}$ ). Due to often large amounts of within-session extinction during extinction retention tests, we found that data from the first block of the extinction retention test best exemplifies levels of between-session extinction. Fearpotentiated startle was calculated as for the preextinction test and data were analyzed using unpaired $t$ test to compare block 1 for the vehicle and NPY groups and paired $t$ test to compare preextinction and postextinction values for each group.

Experiment 8: effect of BIBO 3304 in the amygdala on extinction retention. Five days following the last fear conditioning session, animals were infused bilaterally with vehicle $(n=20)$ or $200 \mathrm{pmol} /$ side BIBO 3304 into either the BLA $(n=15)$ or medial amygdala $(n=7)$ immediately before extinction training consisting of $30 \mathrm{LN}$ and $30 \mathrm{NA}$ stimuli in the absence of footshock ( $30 \mathrm{~s}$ intertrial interval). Animals were then tested $48 \mathrm{~h}$ later with a test (15 LN, $15 \mathrm{NA})$ to evaluate levels of extinction retention. The intra-amygdala dose of BIBO 3304 used was chosen from previous studies in an anxiety paradigm (Sajdyk et al., 1999; Wierońska et al., 2004). In contrast to previous experiments, in this extinction training session startle stimuli were given $3.2 \mathrm{~s}$ after each light (i.e., a LN trial) to evaluate the effects of drug on the expression and extinction of fear-potentiated startle in the same group of animals. A prior parametric study comparing the difference between extinction training with light-alone trials and lightnoise trials indicated that both paradigms yield similar levels of extinction. It should be noted that we did not observe a difference in noisealone values between groups when infusing into the amygdala in previous studies using infusion of BIBO 3304 into the amygdala, and therefore used our standard context for this experiment. Data were analyzed using one-way ANOVA to compare percentage fear-potentiated startle in block 1 for the three groups.

\section{Results}

Experiment 1: central NPY activation inhibits baseline startle Before proceeding with an evaluation of the effects of NPY in our learning paradigms, we generated a dose-response curve (Fig. 2) for the effect of intracerebroventricular administration of $0,1,3$, 


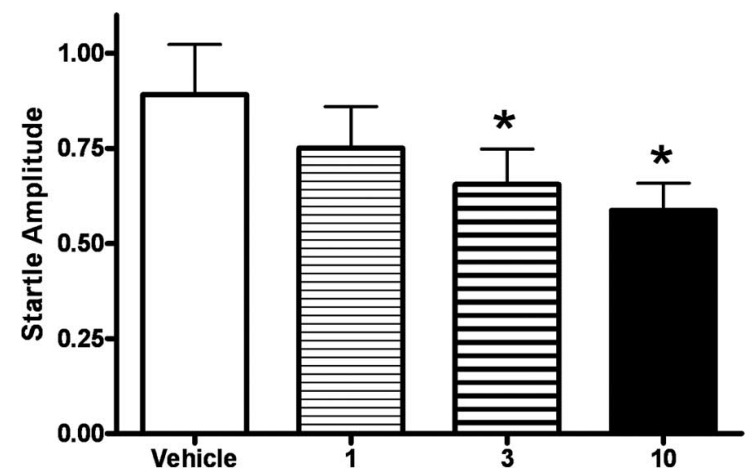

Figure 2. Dose-response curve showing that activation of central NPY receptors inhibits baseline startle. Each animal received an infusion of vehicle, 1, 3, or $10 \mu \mathrm{g}$ of NPY on each of four days in a counterbalanced manner 60 min before baseline startle testing. NPY had a dosedependent effect on decreasing baseline startle [overall effect between treatments $\left(F_{(3,61)}=\right.$ $4.09, p<0.05)$; values shown are the average of all trials; error bars indicate $\pm S E M$; ${ }^{*} p<0.05$ compared with vehicle].

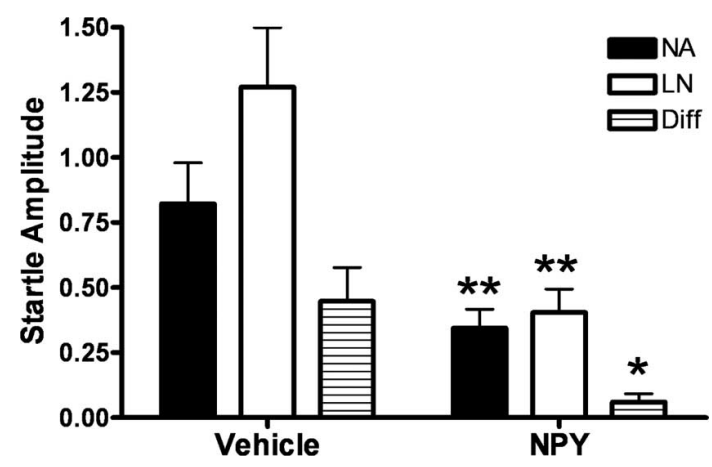

Figure 3. Central NPY activation inhibits the expression of fear-potentiated startle. Animals ( $n=11$ ) were infused intracerebroventricularly with $10 \mu \mathrm{g}$ of NPY or vehicle 60 min before testing. Following NPY infusion, animals exhibited an overall reduction in startle amplitude with NA and LN values significantly lower than in the vehicle condition. NPY administration also led to a significant reduction in percentage fear-potentiated startle during the expression test (error bars indicate \pm SEM; ${ }^{*} p<0.05,{ }^{* *} p<0.01$ ).

and $10 \mu \mathrm{g}$ of NPY on baseline startle. One-way repeatedmeasures ANOVA showed that NPY administration dosedependently decreased baseline startle amplitude, with an overall effect between treatments $\left(p<0.05, F_{(3,61)}=4.09\right)$. StudentNewman-Keuls post hoc analysis indicated significantly lower levels of baseline startle between 3 and $10 \mu \mathrm{g}$ of NPY and vehicle $(p<0.05)$ and a trend-level decrease in baseline startle between $1 \mu \mathrm{g}$ of NPY and vehicle $(p=0.08)$.

Experiment 2: central NPY activation inhibits the expression of fear-potentiated startle

Administration of NPY reduced overall startle amplitude on both noise-alone and light-noise trials compared with the vehicle condition, as well as a significant reduction in the difference score $(\mathrm{LN}-\mathrm{NA}$ ) between conditions (Fig. 3 ) (paired $t$ test, $p<0.01$ ). Importantly, NPY inhibited the expression of fear-potentiated startle, measured as a reduction in percentage fear-potentiated startle (paired $t$ test, $p<0.05$ ), that cannot be accounted for by its overall reduction in startle amplitude.

Experiment 3: intra-basolateral amygdala activation of NPY inhibits the expression of fear-potentiated startle

NPY infusion into the basolateral, but not the medial, nucleus of the amygdala inhibited the expression of fear-potentiated startle
(Fig. 4A). Two-way repeated-measures ANOVA for the BLA group identified a significant overall effect of time $(p<0.001$, $\left.F_{(5,155)}=8.704\right)$ and a time by treatment interaction $(p<0.05$, $\left.F_{(5,155)}=2.897\right)$. Student-Newman-Keuls post hoc analysis revealed a significant difference between NPY and vehicle for block $1(p<0.05)$. No effect was found for the medial amygdala group (Fig. $4 B$ ). NPY had no effect on baseline startle responding in either region (Fig. 4C), indicating that the observed effect on expression of fear-potentiated startle is not merely an effect on the startle reflex itself and that the effects of intracerebroventricular NPY on baseline startle was probably not due to effects on these amygdala nuclei.

\section{Experiment 4: intra-amygdala antagonism of NPY Y1} receptors has no effect on the expression of fear-potentiated startle

Two-way repeated-measures ANOVA indicated that infusion of the NPY $Y_{1}$ receptor antagonist BIBO3304 into the BLA or medial amygdala immediately before testing had no effect of on the expression of fear-potentiated startle (Fig. 5A). There was no observed effect on baseline startle in either region, as measured by NA values during the expression test (Fig. $5 B$ ).

Experiment 5: central NPY activation enhances withinsession extinction of fear-potentiated startle

Figure 6 demonstrates a significant enhancement of withinsession extinction in the NPY condition compared with vehicle. Two-way repeated-measures ANOVA indicates significant main effects for both treatment $\left(F_{(1,131)}=7.235, p<0.05\right)$ and block $\left(F_{(5,131)}=5.444, p<0.001\right)$, although the interaction was not significant. However, Student-Newman-Keuls post hoc analysis indicated that fear-potentiated startle in the NPY group was significantly lower than in the vehicle condition at blocks $4(p<$ $0.01)$ and $6(p<0.01)$.

Experiment 6: central NPY activation enhances extinction to the contextual component of fear-potentiated startle

We did not observe an overall effect of NPY on percentage fearpotentiated startle in our extinction retention test (Fig. 7B). However, we did observe an overall decrease in startle amplitude in the NPY group (two-way repeated-measures ANOVA, significant main effect of treatment $\left(F_{(1,35)}=4.902, p<0.05\right)$ and a significant reduction during noise-alone trials (Fig. 7C) $(p<$ 0.05 ). The baseline change between the vehicle and NPY groups made a comparison between percentage fear difficult to verify, and compelled us to examine this decrease in noise-alone trials further.

In comparing noise-alone startle responses before training (baseline), after training (Pre-Ext), and after extinction (PostExt), two-way repeated-measures ANOVA identified a significant main effect of test session $\left(F_{(2,59)}=6.545, p<0.01\right)$ and Student-Newman-Keuls post hoc analysis revealed an increase in startle response for both groups from baseline to Pre-Ext $(p<$ 0.05), indicative of contextual fear conditioning (Fig. $8 B$ ). In the vehicle group, we observed no difference between our Pre-Ext and Post-Ext values, whereas in the NPY group, there was a reduction in startle response from Pre-Ext to Post-Ext $(p<0.05)$ and no difference between the baseline and Post-Ext startle amplitude. These data suggest that NPY enhanced extinction of contextual conditioning. 


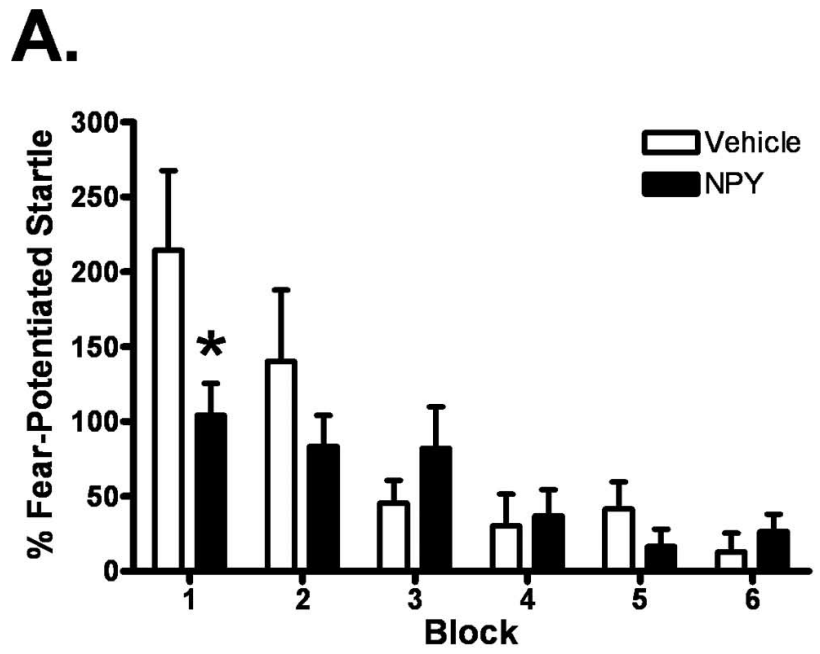

B.

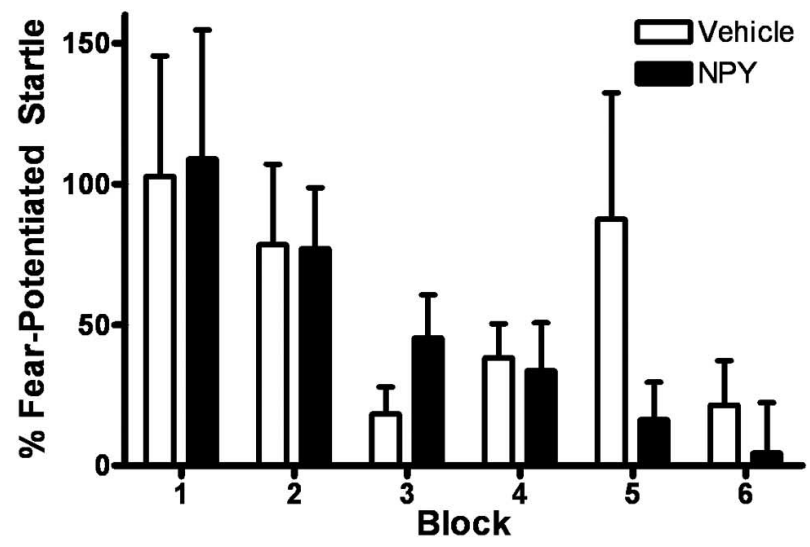

C.

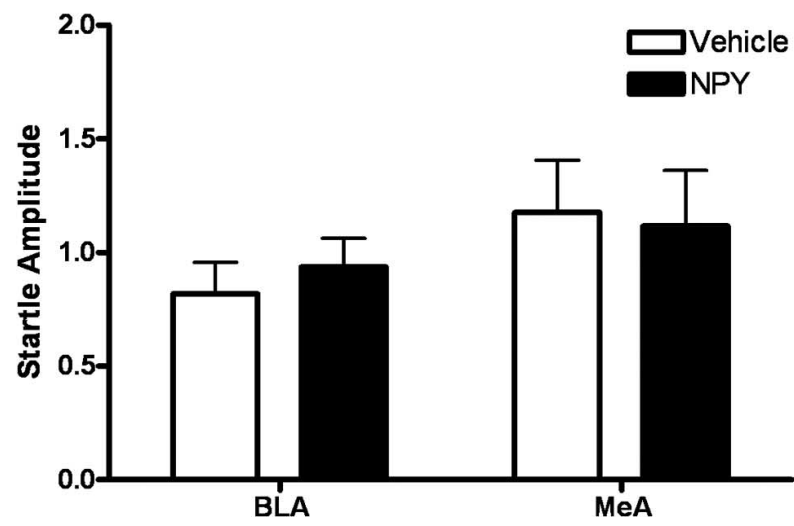

Figure 4. Intra-basolateral amygdala activation of NPY inhibits the expression of fearpotentiated startle. Animals were implanted with bilateral cannulae in the basolateral or medial amygdala 7-10 d before behavioral training. Immediately before the expression test, animals were infused bilaterally with vehicle or $10 \mathrm{pmol}$ of NPY/side. A, Following NPY infusion, animals exhibited a significant decrease in the expression of fear-potentiated startle. There was a significant overall effect of time $\left(p<0.001, F_{(5,155)}=8.704\right)$ and a time by treatment interaction $\left(p<0.05, F_{(5,155)}=2.897\right)$. (values shown are in blocks of 5 trials; error bars indicate \pm SEM; pairwise comparison identified a difference between groups in block 1 ; ${ }^{*} p<$ $0.05)$. $\boldsymbol{B}$, There was no difference between vehicle and NPY conditions following infusion into the medial amygdala. $C$, NPY had no effect on baseline startle in either region, indicating that the effect shown in $\boldsymbol{A}$ is not merely an effect on the startle reflex.

\section{A.}

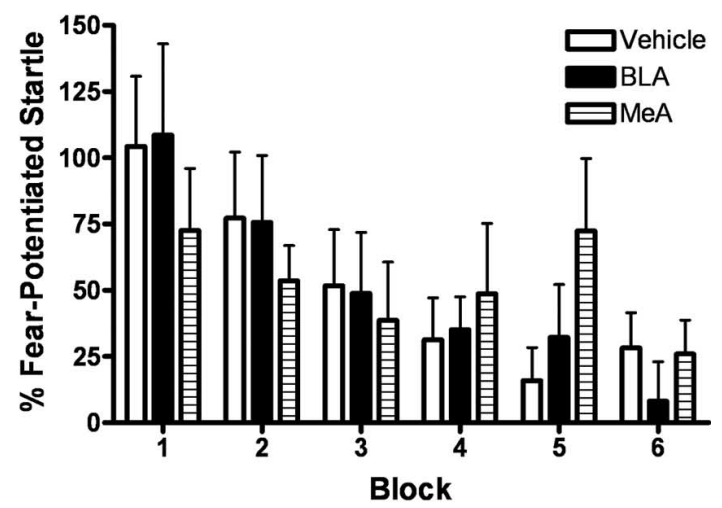

B.

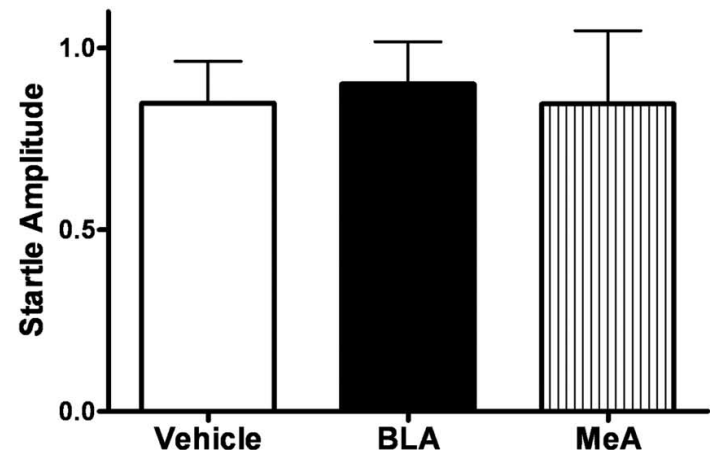

Figure 5. Intra-amygdala antagonism of NPY Y1 receptors has no effect on the expression of fear-potentiated startle. Animals were implanted with bilateral cannulae in the basolateral or medial amygdala 7-10 d before behavioral training. Immediately before the expression test, animals were infused bilaterally with vehicle $(n=20)$ or $200 \mathrm{pmol} / \mathrm{side}$ BIBO 3304 into either the basolateral $(n=15)$ or medial $(n=7)$ amygdala. $A$, Intra-basolateral and intra-medial amygdala administration of BIBO 3304 had no effect on the expression of fear-potentiated startle. $\boldsymbol{B}$, Infusion of BIBO 3304 had no effect on baseline startle in either region.

Experiment 7: central NPY activation enhances the extinction of fear-potentiated startle in an ABB paradigm

Animals who received NPY before extinction training showed significantly lower fear-potentiated startle in the postextinction test than vehicle controls $(p<0.05)$. Furthermore, there was significant extinction in the NPY group $(p<0.001)$ but not in the vehicle group, as measured by a decrease in percentage fearpotentiated startle from preextinction to postextinction. Interestingly, there was no longer a significant difference in baseline startle during the extinction retention test in our groups (Fig. $9 C$ ), indicating that the shift in context was effective in reducing contextual conditioning, allowing NPY's facilitation of extinction of cued conditioning to be detected.

Experiment 8: intra-basolateral amygdala antagonism of NPY Y1 receptors blocks the extinction of fear-potentiated startle In comparing levels of percentage fear-potentiated startle among groups receiving vehicle, $\mathrm{BIBO} 3304$ into the BLA, and BIBO 3304 into the medial amygdala before extinction training, oneway ANOVA identified a significant main effect of treatment (Fig. 10) $\left(F_{(2,40)}=3.281, p<0.05\right)$. Student-Newman-Keuls post hoc analysis indicated that animals that received BIBO3304 into the BLA showed significantly greater fear-potentiated startle during the extinction retention test compared with vehicle $(p<$ 0.05). No effect was observed following BIBO 3304 infusion into 
A.

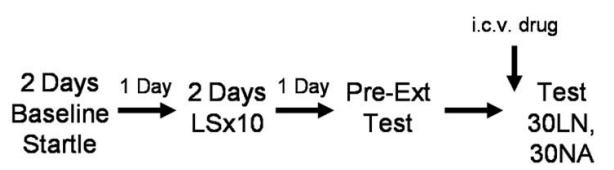

B.

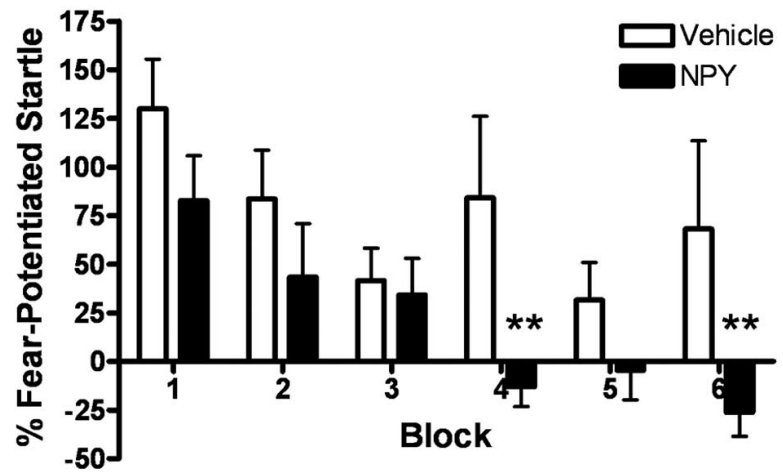

Figure 6. Central NPY activation enhances within-session extinction of fear-potentiated startle. $\boldsymbol{A}$, Implantation of intracerebroventricular cannulae was performed 7-10 $\mathrm{d}$ before behavioral training. Animals ( $n=11$ ) were infused intracerebroventricularly with $10 \mu \mathrm{g}$ of NPY or vehicle 60 min before testing. $\boldsymbol{B}$, Fear-potentiated startle is lower in the NPY condition, especially during the second half of the test session, indicating increased within-session extinction [values shown are blocks of 5 trials; significant main effect for both treatment $\left(F_{(1,131)}=\right.$ $7.235, p<0.05)$ and block $\left(F_{(5,131)}=5.444, p<0.001\right)$; posthoc analysis identified significant difference between vehicle and NPY at blocks 4 and 6 ; error bars indicate $\pm \mathrm{SEM}^{* *} p<0.01$ ].

the medial amygdala. Results from previous experiments indicated that BIBO 3304 had no effect on baseline startle in either region. These results indicated that blockade of Y1 receptors in the amygdala attenuated extinction.

\section{Discussion}

We found that intracerebroventricular administration of NPY enhances the rate of within-session extinction and extinction retention for both contextual and cued aspects of conditioned fear and that antagonism of NPY $Y_{1}$ receptors in the BLA results in decreased extinction retention, suggesting that endogenous NPY is important for the development of extinction.

Additionally, we have shown that administration of exogenous NPY inhibits the expression of fear-potentiated startle. The blockade of fear-potentiated startle was observed after intracerebroventricular and intra-BLA, but not intra-MeA, infusion of NPY. Moreover, we observed a dose-dependent reduction in baseline startle following intracerebroventricular administration of NPY. However, this was not seen in the amygdala, at least at the dose that was used, indicating the effects of NPY on fearpotentiated startle were not an artifact of a change in baseline startle.

Our finding that NPY infusion into the BLA, but not the MeA, inhibits the expression of fear-potentiated startle is consistent with previous findings. NPY is able to inhibit excitatory transmission in the amygdala (A. I. Molosh and D. G. Rainnie, unpublished observations). Electrophysiological data have shown that NPY agonists inhibit glutamate release in the hippocampus (Colmers et al., 1987; Qian et al., 1997). Pharmacological studies have shown that the expression of fear-potentiated startle is dependent on AMPA glutamate receptors in the BLA (Kim et al., 1993; Walker and Davis, 1997; Walker et al., 2005). Therefore, it is likely that NPY is acting to decrease glutaminergic transmission in the BLA, thereby suppressing excitatory output from the amygdala and leading to the observed inhibition of fear-
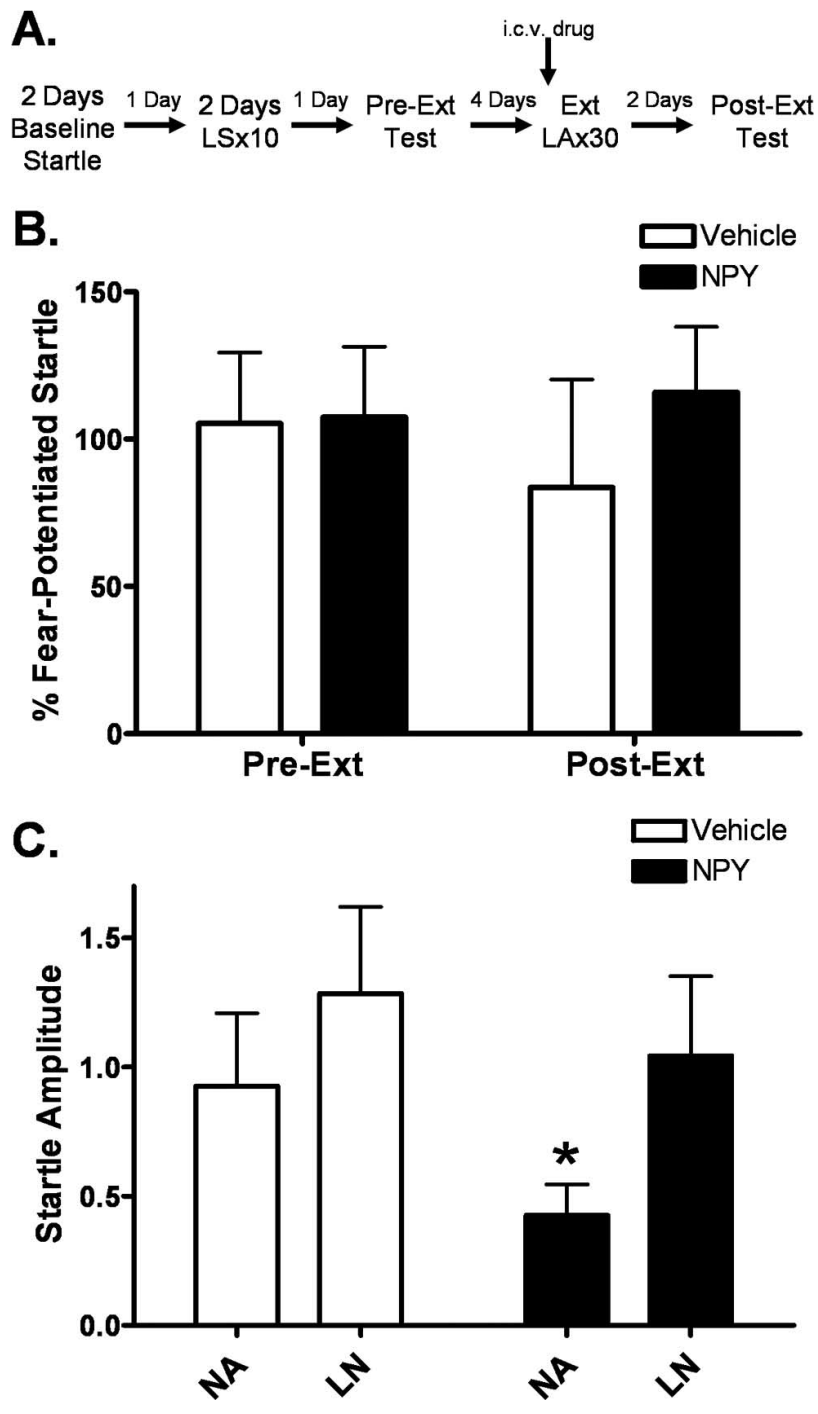

Figure 7. Central administration of NPY before extinction training decreased overall startle amplitude but not percentage fear-potentiated startle. $\boldsymbol{A}$, Animals were implanted with intracerebroventricular cannulae 7-10 d before behavioral training. $30 \mathrm{~min}$ before extinction training, vehicle or $10 \mu \mathrm{g}$ of NPY was infused. Animals were tested $48 \mathrm{~h}$ later with no drug onboard (Post-Ext). B , There was no significant difference in percentage fear-potentiated startle between the vehicle and NPY groups (values shown represent average of first five trials of test). $\boldsymbol{C}$, We observed an overall decrease in startle amplitude and a significant decrease in NA startle values in the NPY group during the Post-Ext test [significant main effect of treatment $\left(F_{(1,35)}=\right.$ $4.902, p<0.05)$; error bars indicate \pm SEM; ${ }^{*} p<0.05$ ].

potentiated startle. We feel that the medial amygdala $(\mathrm{MeA})$ is an ideal control region for these experiments, both because of its proximity to the BLA and because it expresses both NPY receptors and peptide (Chronwall et al., 1985; Parker and Herzog, 1999; Kopp et al., 2002). Some evidence suggests that the central amygdala, a region responsible for output of information from the amygdala (Davis, 2000), is also important for NPY signaling (Heilig et al., 1993; Heilig, 2004). Since the reduction in expression of fear-potentiated startle observed in the BLA was less than that seen with intracerebroventricular infusion, it is possible that another region helps mediate the intracerebroventricular effects. Future experiments can evaluate whether NPY has effects in either the central amygdala or the bed nucleus of the stria terminalis, another output nucleus of the amygdala.

While we attempted to determine the receptor subtype mediating the reduction of fear-potentiated startle, our data remain 


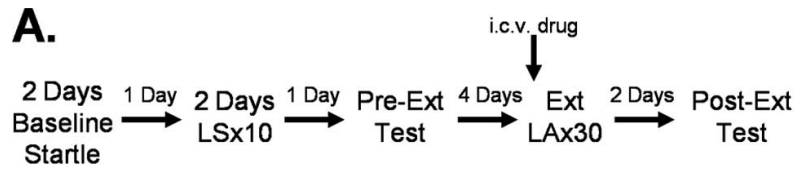

B.

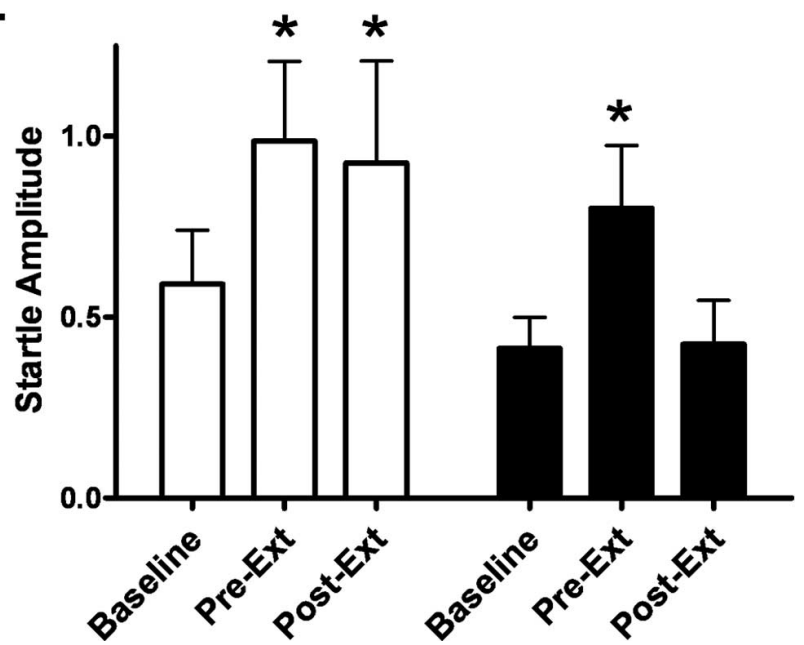

Figure 8. Central administration of NPY enhances the extinction to the contextual component of fear-potentiated startle. $A$, A comparison of noise-alone startle was made among values from three days of the behavioral procedure shown here: (1) baseline (startle amplitude measured before fear conditioning, (2) Pre-Ext test (startle amplitude measured after fear conditioning, before extinction training), and (3) Post-Ext test (startle amplitude measured after extinction training). $\boldsymbol{B}$, In the vehicle group, startle response increases from baseline to Pre-Ext and then remains constant, corresponding to the development and maintenance of contextual fear. However, in the NPY group startle response increases from baseline to Pre-Ext and then decreases to levels comparable to baseline during the Post-Ext test. This pattern corresponds to extinction of contextual fear [significant main effect of test session $\left(F_{(2,59)}=6.545, p<0.01\right)$; error bars indicate \pm SEM; $\left.{ }^{*} p<0.05\right]$.

inconclusive. We were not particularly surprised by the lack of effect of the $Y_{1}$ receptor antagonist BIBO 3304 on the expression of fear-potentiated startle. Other studies have found no effect of BIBO 3304 alone on baseline behavioral measures, such as social interaction (Sajdyk et al., 1999), suggesting the basal tone of NPY in the BLA may not be high enough to observe effects of an antagonist alone. This does not diminish the significance of our findings; rather, it suggests that while enhanced NPY signaling can inhibit the expression of conditioned fear, endogenous NPY is not necessary for normal expression of fear. Alternatively, it is possible that another NPY receptor subtype is involved. $\mathrm{Y}_{5}$ receptors in the BLA are implicated in anxiety-related behaviors (Sajdyk et al., 2002a).

The finding that infusion of BIBO 3304 inhibits extinction of fear-potentiated startle suggests that the $Y_{1}$ receptor modulates regulation of extinction learning in the BLA. This supports previous pharmacologic and genetic studies demonstrating that the $\mathrm{Y}_{1}$ receptor mediate anxiolytic effects of NPY (Kask et al., 2002; Thorsell and Heilig, 2002). $Y_{1}$ receptor agonists increase punished responding in a conflict test (Britton et al., 1997) and antisense inhibition or a $\mathrm{Y}_{1}$ receptor antagonist blocks anxiolytic-like effects of NPY on the elevated plus-maze and social interaction (Heilig, 1995; Sajdyk et al., 1999). Bilateral administration of the nonpeptide $\mathrm{Y}_{1}$ receptor antagonist BIBP3226 into the amygdala results in increased anxiety-related behavior in the elevated plusmaze (Primeaux et al., 2005). A recent study with NPY Y ${ }_{1}$ receptor null mice has shown that the $\mathrm{Y}_{1}$ receptor is necessary for

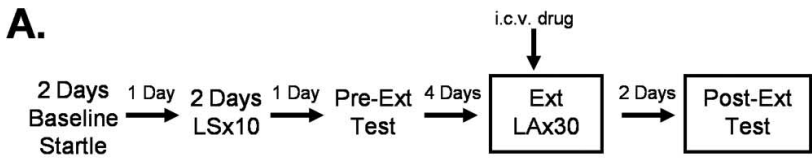

B.
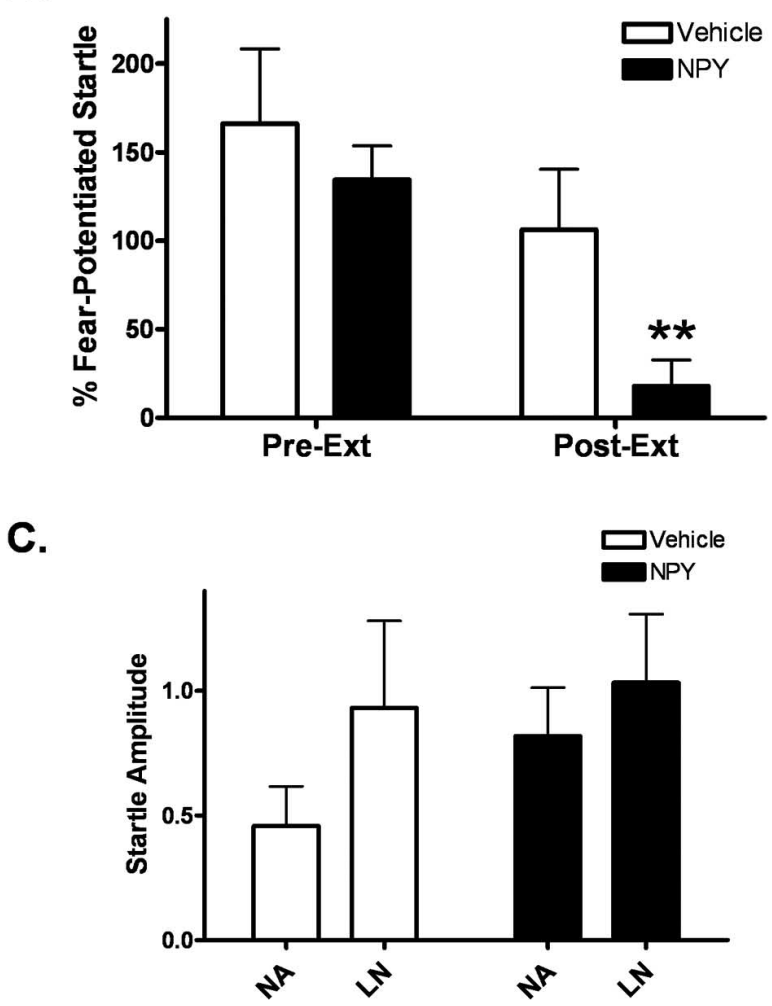

Figure 9. Central administration of NPY enhances the extinction of fear-potentiated startle. $\boldsymbol{A}$, Animals were implanted with intracerebroventricular cannulae 7-10 d before behavioral testing. Animals were baseline tested, trained, and matched with a preextinction test (Pre-Ext) in our standard context. The context was altered for extinction training and testing to decrease the possible confounding effects of contextual conditioning. Before extinction training (30 min), animals were infused with either vehicle or $10 \mu \mathrm{g}$ of NPY. Animals were tested for extinction retention (Post-Ext) $48 \mathrm{~h}$ later off drug. B, Animals infused with NPY had significantly lower percentage fear-potentiated startle during the Post-Ext test than vehicle controls. Additionally, the NPY group shows a significant reduction in percentage fear-potentiated startle from Pre-Ext to Post-Ext, while there is no significant change in the vehicle group. (error bars indicate \pm SEM; ${ }^{* *} p<0.05$ compared with vehicle Post-Ext, $p<0.001$ compared with NPY Pre-Ext). $\boldsymbol{C}$, There was no difference in overall startle amplitude or baseline startle between groups.

anxiolytic-like effects of intracerebroventricular NPY on the elevated plus-maze (Karlsson et al., 2008).

Because we typically see very little context conditioning using our parameters for measuring startle, we train and test animals in the same context. However, the results in experiment 2 indicated considerable context conditioning and suggested that NPY was facilitating its extinction, thereby masking measurement of its possible effect on cue extinction. While the enhancement of extinction to contextual fear is an important finding, we wanted to determine whether or not central administration of NPY could also enhance extinction of cued fear. For this reason, we repeated the previous experiment but altered our testing context for extinction training and postextinction testing (experiment 7).

We no longer saw a difference in noise-alone startle amplitude between our NPY and vehicle groups in the Post-Ext test and were therefore able to compare percentage fear in our groups 
A.

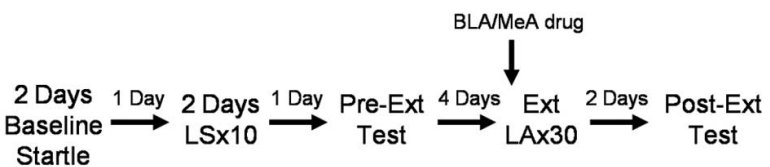

B.

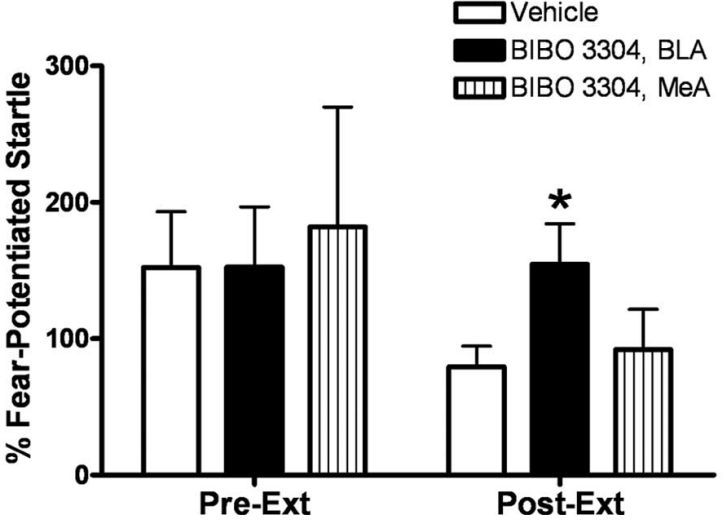

Figure 10. Infusion of the NPY Y1 receptor antagonist BIBO 3304 in the basolateral amygdala blocks the extinction of fearpotentiated startle. $\boldsymbol{A}$, Animals were implanted with bilateral cannulae in the basolateral or medial amygdala $7-10 \mathrm{~d}$ before behavioral training. Immediately before extinction training, animals were infused with either vehicle $(n=20)$ or $200 \mathrm{pmol} / \mathrm{side}$ BIBO 3304 into either the basolateral $(n=15)$ or medial $(n=7)$ amygdala. Animals were tested off drug $48 \mathrm{~h}$ later to assess extinction retention (Post-Ext). B, Animals who received BIBO 3304 into the basolateral amygdala had significantly greater fear-potentiated startle during Post-Ext than vehicle controls. No difference was found for animals who received intra-medial amygdala BIBO 3304 [significant main effect of treatment $\left(F_{(2,40)}=3.281, p<0.05\right)$; error bars indicate \pm SEM; ${ }^{*} p<0.05$ compared with vehicle].

since we no longer had differential shifts in our baseline startle values. Figure 9 shows that the NPY group had significantly lower percentage fear-potentiated startle in the extinction retention test leading to the conclusion that exogenous administration of NPY can enhance both within-session and between-session extinction of fear-potentiated startle. Enhanced retention of extinction measured by lower levels of fear-potentiated startle could conceivably be explained by a lingering effect of NPY on fearpotentiated startle at test. However, we have observed in several other experiments that effects of NPY on baseline or fearpotentiated startle are gone by $48 \mathrm{~h}$ after infusion. While these studies only test at $48 \mathrm{~h}$, we anticipate that these effects will persist long after this time point. Future experiments evaluating spontaneous recovery with this model can further elucidate the duration of the effect.

We chose to infuse an NPY antagonist, and not NPY peptide, into the BLA because antagonist studies provide a more direct approach for evaluating how endogenous systems function. Significantly higher levels of percentage fear-potentiated startle during the extinction retention test were found following infusion of BIBO 3304 into the BLA. This demonstrates that blockade of NPY interferes with normal extinction and suggests that under normal conditions endogenous NPY $Y_{1}$ receptors are activated during the extinction of conditioned fear. Remarkably, BIBO 3304 has no effect on baseline startle or expression of fear-potentiated startle when infused into the BLA (experiment 4) thereby supporting the notion that our observed effects on extinction retention are not due to lingering effects of the drug itself but rather modulation of learning in the BLA.

Extinction of conditioned fear is dependent on NMDA glutamate receptors in the amygdala (Falls et al., 1992; Sotres-Bayon et al., 2007). GABAergic interneurons mediate inhibition of glutaminergic excitatory transmission in the basolateral amygdala (Rainnie et al., 1991). Studies evaluating the electrophysiological effects of NPY in the arcuate nucleus indicate that NPY can in- hibit GABAergic transmission (AcunaGoycolea et al., 2005). It is possible that NPY could be inhibiting a subpopulation of interneurons in the BLA, thereby disinhibiting the glutaminergic neurons responsible for extinction.

In conclusion, we believe that increases of NPY in the hippocampus when rats are exposed to a fearful context (Teppen and Urban, 2003) or in the amygdala following a fearful cue (Gutman, Ressler, and Davis, unpublished observations) reflect its involvement in extinction and that its ability to improve resilience is based, in part, on its facilitation of extinction. This might also predict that enhancement of NPY Y receptor activation could be a potential adjunct for extinction-based psychotherapy, such as exposure therapy. Currently, the lack of available nonpeptide systemic NPY $Y_{1}$ receptor agonists prohibits the direct clinical testing of this approach. An alternative strategy would take advantage of the presynaptic autoreceptor function of NPY $\mathrm{Y}_{2}$ receptors, which have been found to inhibit transmitter release (Michel et al., 1998). Administration of antagonists to the NPY $\mathrm{Y}_{2}$ autoreceptor could lead to an endogenous enhancement of NPY $Y_{1}$ receptor activation. This autoreceptor function may explain why administration of BIIE0246, a selective NPY $\mathrm{Y}_{2}$ receptor antagonist, has an anxiolytic-like effect in the elevated plus-maze in rats (Bacchi et al., 2006). Genetic manipulation of the $Y_{2}$ receptor further support this hypothesis, with $Y_{2}$ receptor knock-out mice exhibiting reduced anxiety in the open field and elevated plus-maze (Redrobe et al., 2003; Tschenett et al., 2003). Further studies are necessary to evaluate the merit of this approach in other models. Finally, it is conceivable that the ability of NPY to facilitate extinction observed in the present study might in some way be connected to the association between resilience and enhanced levels of NPY, such as those observed in soldiers under high stress and following trauma in individuals who do not develop PTSD (Morgan et al., 2000; Yehuda et al., 2006).

\section{References}

Acuna-Goycolea C, Tamamaki N, Yanagawa Y, Obata K, van den Pol AN (2005) Mechanisms of neuropeptide Y, peptide YY, and pancreatic polypeptide inhibition of identified green fluorescent protein-expressing GABA neurons in the hypothalamic neuroendocrine arcuate nucleus. J Neurosci 25:7406-7419.

Bacchi F, Mathé AA, Jiménez P, Stasi L, Arban R, Gerrard P, Caberlotto L (2006) Anxiolytic-like effect of the selective neuropeptide Y Y2 receptor antagonist BIIE0246 in the elevated plus-maze. Peptides 27:3202-3207.

Britton KT, Southerland S, Van Uden E, Kirby D, Rivier J, Koob G (1997) Anxiolytic activity of NPY receptor agonists in the conflict test. Psychopharmacology 132:6-13.

Broqua P, Wettstein JG, Rocher MN, Gauthier-Martin B, Junien JL (1995) Behavioral effects of neuropeptide $\mathrm{Y}$ receptor agonists in the elevated plus-maze and fear-potentiated startle procedures. Behav Pharmacol 6:215-222.

Cassella JV, Davis M (1986) The design and calibration of a startle measurement system. Physiol Behav 36:377-383.

Chronwall BM, DiMaggio DA, Massari VJ, Pickel VM, Ruggiero DA, O'Donohue TL (1985) The anatomy of neuropeptide-Y-containing neurons in rat brain. Neuroscience 15:1159-1181.

Colmers WF, Lukowiak K, Pittman QJ (1987) Presynaptic action of neu- 
ropeptide $\mathrm{Y}$ in area $\mathrm{CA} 1$ of the rat hippocampal slice. J Physiol 383:285-299.

Conrad CD, McEwen BS (2000) Acute stress increases neuropeptide Y mRNA within the arcuate nucleus and hilus of the dentate gyrus. Brain Res Mol Brain Res 79:102-109.

Davis M (2000) The role of the amygdala in conditioned and unconditioned fear and anxiety. In: The amygdala (Aggleton JP, ed), pp 213-287. New York: Oxford UP.

Falls WA, Miserendino MJ, Davis M (1992) Extinction of fear-potentiated startle: blockade by infusion of an NMDA antagonist into the amygdala. J Neurosci 12:854-863.

Flood JF, Baker ML, Hernandez EN, Morley JE (1989) Modulation of memory processing by neuropeptide $\mathrm{Y}$ varies with brain injection site. Brain Res 503:73-82.

Heilig M (1995) Antisense inhibition of neuropeptide Y (NPY)-Y1 receptor expression blocks the anxiolytic-like action of NPY in amygdala and paradoxically increases feeding. Regul Pept 59:201-205.

Heilig M (2004) The NPY system in stress, anxiety and depression. Neuropeptides 38:213-224.

Heilig M, Söderpalm B, Engel JA, Widerlöv E (1989) Centrally administered neuropeptide Y (NPY) produces anxiolytic-like effects in animal anxiety models. Psychopharmacology 98:524-529.

Heilig M, McLeod S, Koob GK, Britton KT (1992) Anxiolytic-like effect of neuropeptide Y (NPY), but not other peptides in an operant conflict test. Regul Pept 41:61-69.

Heilig M, McLeod S, Brot M, Heinrichs SC, Menzaghi F, Koob GF, Britton KT (1993) Anxiolytic-like action of neuropeptide Y: mediation by Y1 receptors in amygdala, and dissociation from food intake effects. Neuropsychopharmacology 8:357-363.

Karlsson RM, Choe JS, Cameron HA, Thorsell A, Crawley JN, Holmes A, Heilig M (2008) The neuropeptide Y Y1 receptor subtype is necessary for the anxiolytic-like effects of neuropeptide $Y$, but not the antidepressant-like effects of fluoxetine, in mice. Psychopharmacology 195:547-557.

Kask A, Kivastik T, Rägo L, Harro J (1999) Neuropeptide Y Y1 receptor antagonist BIBP3226 produces conditioned place aversion in rats. Prog Neuropsychopharmacol Biol Psychiatry 23:705-711.

Kask A, Harro J, von Hörsten S, Redrobe JP, Dumont Y, Quirion R (2002) The neurocircuitry and receptor subtypes mediating anxiolytic-like effects of neuropeptide Y. Neurosci Biobehav Rev 26:259-283.

Kim M, Campeau S, Falls WA, Davis M (1993) Infusion of the non-NMDA receptor antagonist CNQX into the amygdala blocks the expression of fear-potentiated startle. Behav Neural Biol 59:5-8.

Kokare DM, Dandekar MP, Chopde CT, Subhedar N (2005) Interaction between neuropeptide $\mathrm{Y}$ and alpha-melanocyte stimulating hormone in amygdala regulates anxiety in rats. Brain Res 1043:107-114.

Kopp J, Xu ZQ, Zhang X, Pedrazzini T, Herzog H, Kresse A, Wong H, Walsh $\mathrm{JH}$, Hökfelt T (2002) Expression of the neuropeptide Y Y1 receptor in the CNS of rat and of wild-type and Y1 receptor knock-out mice. Focus on immunohistochemical localization. Neuroscience 111:443-532.

McDonald AJ, Pearson JC (1989) Coexistence of GABA and peptide immunoreactivity in non-pyramidal neurons of the basolateral amygdala. Neurosci Lett 100:53-58.

Michel MC, Beck-Sickinger A, Cox H, Doods HN, Herzog H, Larhammar D, Quirion R, Schwartz T, Westfall T (1998) XVI. International Union of Pharmacology recommendations for the nomenclature of neuropeptide Y, peptide YY, and pancreatic polypeptide receptors. Pharmacol Rev 50:143-150.

Morgan CA 3rd, Wang S, Southwick SM, Rasmusson A, Hazlett G, Hauger RL, Charney DS (2000) Plasma neuropeptide-Y concentrations in humans exposed to military survival training. Biol Psychiatry 47:902-909.

Nakajima M, Inui A, Teranishi A, Miura M, Hirosue Y, Okita M, Himori N, Baba S, Kasuga M (1994) Effects of pancreatic polypeptide family peptides on feeding and learning behavior in mice. J Pharmacol Exp Ther 268:1010-1014.

Parker RM, Herzog H (1999) Regional distribution of Y-receptor subtype mRNAs in rat brain. Eur J Neurosci 11:1431-1448.

Primeaux SD, Wilson SP, Cusick MC, York DA, Wilson MA (2005) Effects of altered amygdalar neuropeptide Y expression on anxiety-related behaviors. Neuropsychopharmacology 30:1589-1597.

Qian J, Colmers WF, Saggau P (1997) Inhibition of synaptic transmission by neuropeptide $\mathrm{Y}$ in rat hippocampal area CA1: modulation of presynaptic $\mathrm{Ca}^{2+}$ entry. J Neurosci 17:8169-8177.

Rainnie DG, Asprodini EK, Shinnick-Gallagher P (1991) Inhibitory transmission in the basolateral amygdala. J Neurophysiol 66:999-1009.

Redrobe JP, Dumont Y, Herzog H, Quirion R (2003) Neuropeptide Y (NPY) Y2 receptors mediate behaviour in two animal models of anxiety: evidence from Y2 receptor knockout mice. Behav Brain Res 141:251-255.

Redrobe JP, Dumont Y, Herzog H, Quirion R (2004) Characterization of neuropeptide $\mathrm{Y}, \mathrm{Y}(2)$ receptor knockout mice in two animal models of learning and memory processing. J Mol Neurosci 22:159-166.

Sajdyk TJ, Vandergriff MG, Gehlert DR (1999) Amygdalar neuropeptide Y Y1 receptors mediate the anxiolytic-like actions of neuropeptide $Y$ in the social interaction test. Eur J Pharmacol 368:143-147.

Sajdyk TJ, Schober DA, Gehlert DR (2002a) Neuropeptide Y receptor subtypes in the basolateral nucleus of the amygdala modulate anxiogenic responses in rats. Neuropharmacology 43:1165-1172.

Sajdyk TJ, Schober DA, Smiley DL, Gehlert DR (2002b) Neuropeptide Y-Y2 receptors mediate anxiety in the amygdala. Pharmacol Biochem Behav 71:419-423.

Sajdyk TJ, Johnson PL, Leitermann RJ, Fitz SD, Dietrich A, Morin M, Gehlert DR, Urban JH, Shekhar A (2008) Neuropeptide Y in the amygdala induces long-term resilience to stress-induced reductions in social responses but not hypothalamic-adrenal-pituitary axis activity or hyperthermia. J Neurosci 28:893-903.

Sotres-Bayon F, Bush DE, LeDoux JE (2007) Acquisition of fear extinction requires activation of NR2B-containing NMDA receptors in the lateral amygdala. Neuropsychopharmacology 32:1929-1940.

Teppen TL, Urban JH (2003) Regulation of neuropeptide Y (NPY) expression in the amygdala and hippocampus in a rodent model of conditioned fear. In: Soc Neurosci Abstr 29:397.14.

Thorsell A, Heilig M (2002) Diverse functions of neuropeptide Y revealed using genetically modified animals. Neuropeptides 36:182-193.

Thorsell A, Svensson P, Wiklund L, Sommer W, Ekman R, Heilig M (1998) Suppressed neuropeptide Y (NPY) mRNA in rat amygdala following restraint stress. Regul Pept 75-76:247-254.

Thorsell A, Carlsson K, Ekman R, Heilig M (1999) Behavioral and endocrine adaptation, and up-regulation of NPY expression in rat amygdala following repeated restraint stress. Neuroreport 10:3003-3007.

Thorsell A, Michalkiewicz M, Dumont Y, Quirion R, Caberlotto L, Rimondini R, Mathé AA, Heilig M (2000) Behavioral insensitivity to restraint stress, absent fear suppression of behavior and impaired spatial learning in transgenic rats with hippocampal neuropeptide Y overexpression. Proc Natl Acad Sci U S A 97:12852-12857.

Tschenett A, Singewald N, Carli M, Balducci C, Salchner P, Vezzani A, Herzog H, Sperk G (2003) Reduced anxiety and improved stress coping ability in mice lacking NPY-Y2 receptors. Eur J Neurosci 18:143-148.

Walker DL, Davis M (1997) Double dissociation between the involvement of the bed nucleus of the stria terminalis and the central nucleus of the amygdala in startle increases produced by conditioned versus unconditioned fear. J Neurosci 17:9375-9383.

Walker DL, Paschall GY, Davis M (2005) Glutamate receptor antagonist infusions into the basolateral and medial amygdala reveal differential contributions to olfactory vs. context fear conditioning and expression. Learn Mem 12:120-129.

Wieland HA, Willim KD, Entzeroth M, Wienen W, Rudolf K, Eberlein W, Engel W, Doods HN (1995) Subtype selectivity and antagonistic profile of the nonpeptide Y1 receptor antagonist BIBP 3226. J Pharmacol Exp Ther 275:143-149.

Wieland HA, Engel W, Eberlein W, Rudolf K, Doods HN (1998) Subtype selectivity of the novel nonpeptide neuropeptide Y Y1 receptor antagonist BIBO 3304 and its effect on feeding in rodents. Br J Pharmacol 125:549-555.

Wierońska JM, Smiałowska M, Brański P, Gasparini F, Kłodzińska A, Szewczyk B, Pałucha A, Chojnacka-Wójcik E, Pilc A (2004) In the amygdala anxiolytic action of mGlu5 receptors antagonist MPEP involves neuropeptide Y but not GABAA signaling. Neuropsychopharmacology 29:514-521.

Yehuda R, Brand S, Yang RK (2006) Plasma neuropeptide Y concentrations in combat exposed veterans: relationship to trauma exposure, recovery from PTSD, and coping. Biol Psychiatry 59:660-663. 